\title{
Analysis of Plasma-activated Medium (PAM) in aqueous solution by an Atmospheric Pressure Plasma Jet (APPJ)
}

\author{
Andi Wibowo Kinandana ${ }^{1,2, *}$, Sumariyah Sumariyah ${ }^{1,2}$, and Muhammad Nur ${ }^{1,2}$ \\ ${ }^{1}$ Diponegoro University, Physics Department, Faculty of Science and Mathematics, Semarang, Indonesia \\ ${ }^{2}$ Diponegoro University, Center for Plasma Research, Faculty of Science and Mathematics, Semarang, Indonesia
}

\begin{abstract}
Plasma-activated medium (PAM) has been produced by exposing a liquid media to Argon plasma jet. The jet plasma exposure to liquid media has produced reactive Oxygen species (ROS) in liquid phase. This study aims to determine the number of reactive species in plasma-activated medium. An atmospheric pressure plasma jet (APPJ) was generated with a dielectric barrier discharge (DBD) column by $\mathrm{AC}$ high voltage. Some parameters varied including exposure time; i.e. 5, 10, 15, 20, 25, and 30 min; and the distance between reactor and active media; i.e. 1, 2 and $3 \mathrm{~cm}$. Some analysis conducted including variation of exposure times, the distances of reactor to PAM which affect produced concentration, and the reactive species composition in plasma-activated medium. In addition, temperature characteristics, $\mathrm{pH}$ levels, dissolved ozone and dissolved hydrogen peroxide concentrations were also observed in this study. The results showed that increased exposure time resulted in decreased $\mathrm{pH}$, increased temperature and increased concentrations of ozone and hydrogen peroxide. The maximum reactive species composition was obtained at the distance between reactor and plasma-activated medium of $2 \mathrm{~cm}$. Maximum reactive species composition obtained in this study has temperature of 29-30 Celsius degrees; $\mathrm{pH} 3.5$; dissolved ozone 2.97 ppm; and Hydrogen Peroxide 215 ppm.
\end{abstract}

\section{Introduction}

An atmospheric pressure plasma jet (APPJ) in the treatment of aqueous solution has been the subject of considerable interest in the field of medical technology. APPJ can be applied to wound healing [1,2], sterilization [3], coagulation [4], dental treatment [5], and also for the inactivation of various cancer cells [6] such as breast cancer [7], head and neck [8], brain [9], skin [10], ovaries [11], lung [12], prostate [13], and colorectal tissue [14]. It has been proven that plasma species can inactivate cancer cells either directly interactions of gaseous species with cells or indirectly by using plasmaactivated medium (PAM) [15].

PAM is a medium that is irradiated with plasma [16]. PAM has been produced by exposing a liquid media to Argon plasma jet. The jet plasma exposure to liquid media has produced Reactive Oxygen Species (ROS) and Reactive Nitrogen Species (RNS) in liquid phase [15]. ROS and RNS in the aqueous state play a key role in the anti-cancer effects of PAM. The biological effects of plasma are significantly due to changes in plasma induction to cells in the fluid [17]. ROS and RNS diffuses to surface water and dissolves quickly [18]. Reactive species produced by plasma can interact with cells and tissues. Plasma interactions with liquid media through the PAM-making process lead to diffusion / spread of reactive species into the media. The concentration of reactive species produced in PAM is directly related to the duration of plasma exposure and the resulting chemical compounds. The effectiveness of PAM is highly dependent upon the dose of reactive species. The concentrations of reactive species and consequently the effectiveness of PAM decrease over time after plasma exposure [19].

Research on the identification of PAM by plasma jet has been done by Chauvin in 2017. The identification includes the reactive species produced by PAM, as well as the quantitative measurement of reactive Oxygen and Nitrogen species (RONS) in Milli-Q water medium, Dulbecco's Modified Eagle Medium (DMEM). Identification and quantification were performed using electron paramagnetic resonance, fluorometric and colorimetric analyses. The study resulted in the formation of RONS such as hydroxyl radicals, superoxide anions and single oxygen in micromolar concentrations, and the main species produced were Nitric oxide and Hydrogen peroxide in range of several hundred micro molars.

The composition in PAM has a major impact on the $\mathrm{pH}$ of the solution during jet plasma exposure, it affects the stability and production of RONS and it is reactivity with biomolecules. RONS components and oxidized biological compounds may contribute to producing cytotoxic effects in PAM. Long lifetime species in PAM (Hydrogen peroxide and Nitrite / Nitrate) can penetrate cells and can be potential precursors of intracellular reactive oxygen species. PAM provides cytotoxic and

\footnotetext{
* Corresponding author: andikinandana@st.fisika.undip.ac.id
} 
genotoxic effects that can be exploited in various applications, especially for the inactivation of cancer cells. PAM has many advantages including allowing selective treatment of cancerous organ tissues that are difficult to reach by gaseous species and require endoscopy or catheters, resulting in minimal toxicity for normal tissue, and can survive some days after activation if stored at appropriate temperatures [15].

The reactive species in plasma-activated medium have highly reactive, short lifetime and unstable. Therefore, it is necessary to conduct research to identify and quantify reactive species on the plasma-activated medium of Argon jet plasma exposure. The identification aims to knowing the properties and compounds present in the plasma-activated medium, as well as knowing the characteristics of the plasmaactivated medium. Quantification aims to knowing the concentration of reactive species present in the plasma activated medium. In this research, analysis conducted including variation of exposure times, the distances of reactor to PAM which affect produced concentration, and the reactive species composition in plasma-activated medium. Identification and quantification related characteristics of temperature, $\mathrm{pH}$ levels, dissolved ozone and dissolved hydrogen peroxide concentrations.

\section{Method}

This research was conducted by Analysis of Plasmaactivated medium in Aqueous Solution by an Atmospheric Pressure Plasma Jet (APPJ). This Atmospheric Pressure Plasma Jet was generated by AC high voltage. The plasma jet system that we used here is similar to the device developed by Nur et al [20]. The research equipment scheme can be seen in figure 1 .

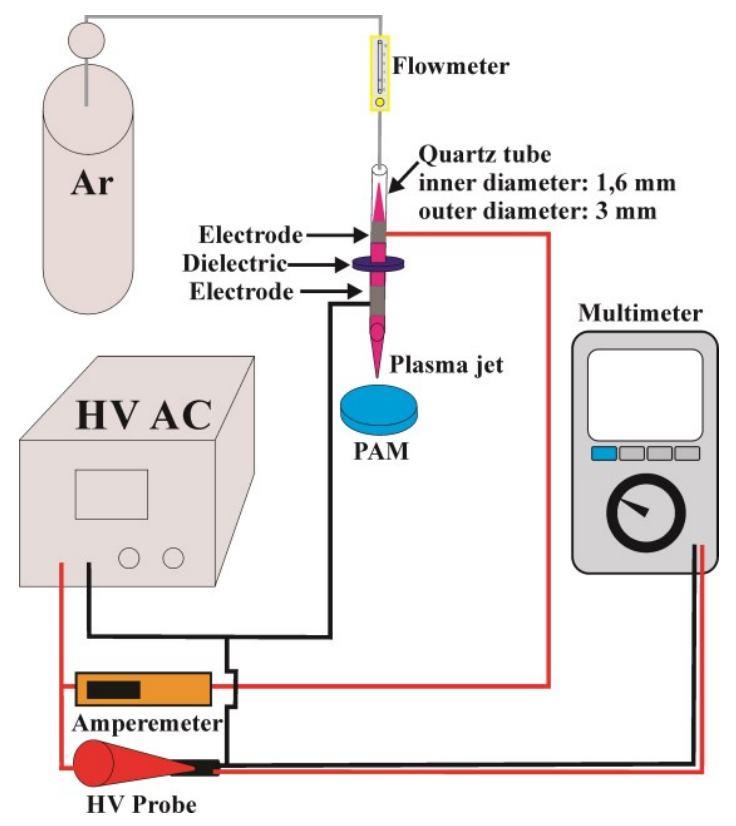

Fig. 1. The research equipment scheme.

A sinusoidal voltage at $12 \mathrm{kV}$ and at frequency 26 $\mathrm{kHz}$ is applied for the excitation and sustaining of the discharges. Argon plasma jet was generated by using the capillary column as plasma jet tube. Figure 2 shows a diagram of the plasma jet device based on a dielectric barrier discharge configuration. AC high voltage source connected to an electrode and HV probe. The capillary column made of quartz glass with an inner diameter of $1.6 \mathrm{~mm}$ and an outer diameter of $3 \mathrm{~mm}$ with a length of $100 \mathrm{~mm}$. At the centre of the length capillary column, we added a Teflon cylinder with a diameter of $2.5 \mathrm{~mm}$ and a length of $2 \mathrm{~mm}$. The Teflon cylinder serves as a dielectric barrier to separate the two electrodes. The electrodes used in this study is made of aluminium (aluminium foil). Two aluminium tape electrodes are wrapped around a quartz capillary column and connected to a High-voltage. The top electrode length of $20 \mathrm{~mm}$ and $30 \mathrm{~mm}$ of the lower electrode, the distance between the electrodes of $10 \mathrm{~mm}$ and the spacing between lower electrode to the tip of the capillary column is $5 \mathrm{~mm}$. Argon gas (purity of $99.999 \%$, Samator Gas products) was supplied at a flow rate $2 \mathrm{~L} /$ minutes into the capillary column.

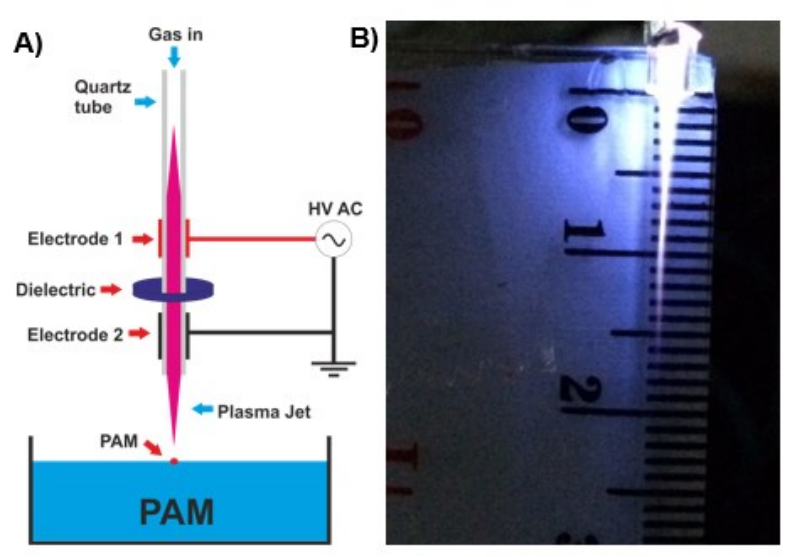

Fig. 2. Plasma jet at atmospheric pressure. (A) Schematic diagram of plasma device. (B) Picture of plasma jet.

PAM in this research is made from materials of aquadest (distilled water) and $\mathrm{H}_{2} \mathrm{O}_{2}$. PAM with aquadest was used to determine temperature, $\mathrm{pH}$, and ozone concentration, while PAM with $\mathrm{H}_{2} \mathrm{O}_{2}$ was used to determine the concentration of $\mathrm{H}_{2} \mathrm{O}_{2}$ produced by Argon jet plasma. PAM samples with aquadest were used with a volume of $25 \mathrm{ml}$. PAM sample with $\mathrm{H}_{2} \mathrm{O}_{2}$ using $\mathrm{H}_{2} \mathrm{O}_{2}$ $30 \%$ dissolved by aquadest. $\mathrm{H}_{2} \mathrm{O}_{2} 30 \%$ was dissolved by using aquadest to concentration of $1000 \mathrm{ppm}$ with $25 \mathrm{ml}$ volume. The PAM sample was then placed into a petri dish under the plasma jet reactor. When the plasma jet is turned on the plasma jet will be about the sample under the reactor with a certain time so that it will become the plasma activated medium. The preparation of PAM was carried out with time exposure $(t)$ of jet plasma for 5,10 , $15,20,25,30,35$ minutes with the distance (d) between electrode to plasma-activated medium was $1,2,3 \mathrm{~cm}$. 


\section{Result and Discussion}

\subsection{Analysis of Temperature in PAM}

In this study, the temperature characteristics of plasmaactivated medium resulted from exposure of plasma jet to aquadest water with an exposure time of 5 to 30 minutes at intervals of 5 minutes with the distance (d) between electrode to plasma-activated medium at 1,2 and $3 \mathrm{~cm}$ from the jet plasma reactor. The temperature of PAM was measured using an infrared thermometer (Krisbow KW06-280). The aim of this treatment is to determine the temperature at PAM after treatment using plasma jet. Based on the result obtained temperature value at PAM shown in Figure 3.

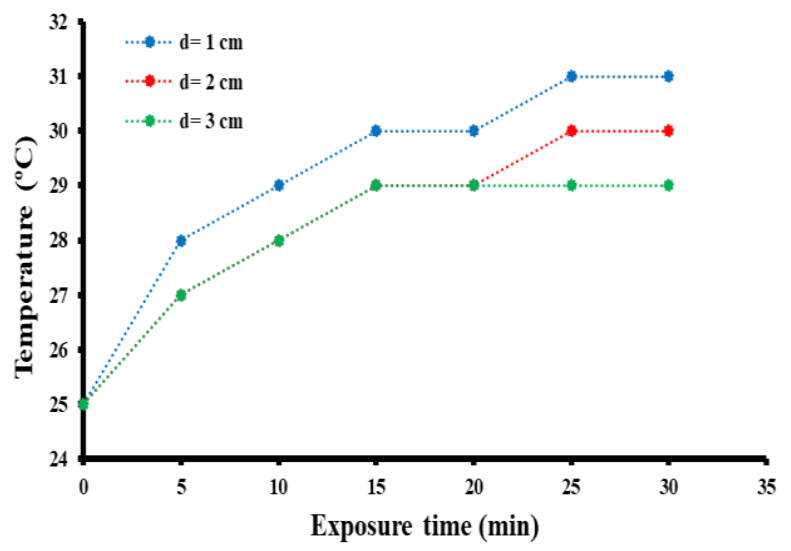

Fig. 3. Graph of temperature as functions of exposure time plasma jet.

Based on the result obtained temperature value at PAM shown in Figure 3. The temperature generated at PAM without jet plasma treatment showed a temperature of $25^{\circ} \mathrm{C}$. Temperatures at PAM without plasma treatment were used as control samples. The sample at a distance of $1 \mathrm{~cm}(\mathrm{~d}=1)$ yields a temperature of $25,28,29,30,30$, $31,31^{\circ} \mathrm{C}$ at the exposure time of $0,5,10,15,20,25,30$ min. The sample result at a distance of $2 \mathrm{~cm}(\mathrm{~d}=2)$ yields a temperature of $25,27,28,29,29,30,30^{\circ} \mathrm{C}$ at the exposure time of $0,5,10,15,20,25,30 \mathrm{~min}$. The sample result at a distance of $3 \mathrm{~cm}(\mathrm{~d}=3)$ yields a temperature of $25,27,28,29,29,29,29^{\circ} \mathrm{C}$ at the exposure time of 0,5 , $10,15,20,25,30 \mathrm{~min}$.

Exposure to Argon jet plasma results in an increase in PAM temperature compared to the temperature of the control sample. PAM temperature against exposure time indicates the temperature increases and then stabilizes at a certain temperature, at $\mathrm{d}=1 \mathrm{~cm}$ stable temperature at 31 ${ }^{\circ} \mathrm{C}, \mathrm{d}=2 \mathrm{~cm} 30{ }^{\circ} \mathrm{C}$, and $\mathrm{d}=3 \mathrm{~cm} 29^{\circ} \mathrm{C}$. The characteristic of PAM temperature to the distance of the reactor shows the greater the distance resulting in decreasing temperature at PAM. Temperature characteristics are caused by interactions between plasma jets and PAM surfaces. The greatest interaction occurs at the distance (d) between electrode to PAM surface $1 \mathrm{~cm}$, at this distance plasma jet directly on the PAM surface resulting in the highest temperature. At the distance (d) between electrode to PAM surface $3 \mathrm{~cm}$ the plasma jet does not affect the PAM surface resulting in the lowest temperature.

\subsection{Analysis of pH in PAM}

In this study $\mathrm{pH}$ analysis on plasma-activated medium resulting from exposure to jet plasma to the sample. The sample of PAM used was aquadest with a volume of 25 $\mathrm{ml}$. The sample is placed on a petri dish under the reactor. This treatment was performed with exposure time of 5 to 30 minutes with interval for 5 minutes with a distance (d) between electrode to plasma-activated medium at 1,2 and $3 \mathrm{~cm}$. The $\mathrm{pH}$ measurements in the sample were performed using a digital $\mathrm{pH}$ meter (ATC $\mathrm{pH}$ ). This treatment to determine the level of acidity in PAM after treatment using plasma jet.

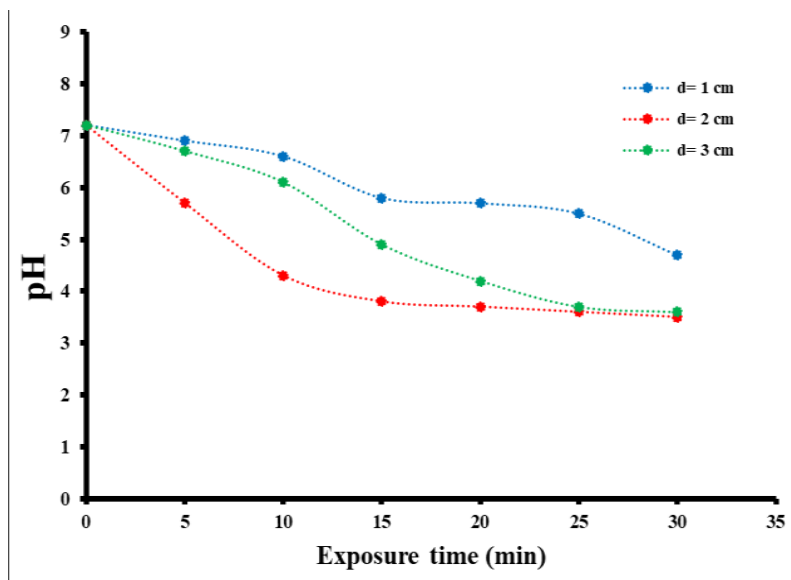

Fig. 4. Graph of $\mathrm{pH}$ as functions of exposure time plasma jet.

Based on the results obtained $\mathrm{pH}$ on PAM can be seen in the graph shown in Figure 4. The $\mathrm{pH}$ without plasma jet treatment ( 0 minutes) showed at 7.2. The samples without plasma treatment were used as control samples. The $\mathrm{pH}$ in PAM with plasma jet exposure with for 0,5 , $10,15,20,25,30$ minutes, at $\mathrm{d}=1 \mathrm{pH} 7.2,6.9,6.6,5.8$, 5.7, 5.5, 4.7 respectively, at $\mathrm{d}=2 \mathrm{pH} \mathrm{7.2,} \mathrm{5.7,} \mathrm{4.3,} \mathrm{3.8,}$ $3.7,3.6,3.5$ respectively, at $\mathrm{d}=3 \mathrm{pH} \mathrm{7.2,} \mathrm{6.7,} \mathrm{6.1,} \mathrm{4.9,}$ $4.2,3.7,3.6$ respectively.

Based on the results obtained showed a decrease in $\mathrm{pH}$ along with the exposure time plasma jet. In the subsequent treatment, the $\mathrm{pH}$ of PAM decreased to 3.5 with plasma jet treatment for 30 minutes at $\mathrm{d}=2$. Decreased $\mathrm{pH}$ indicates change acidity in PAM. PAM samples that were originally neutral conditions $(\mathrm{pH} 7.2)$ after exposure to plasma jet changed to acid. The decrease in $\mathrm{pH}$ is due to the generation of Hydrogen ion $\left(\mathrm{H}^{+}\right)$in the PAM solution. This result indicates that the concentration of Hydrogen ion in the PAM solution increases as a result of plasma jet exposure.

One of the most important chemical effects present in plasma is acidification. Plasma exposure to the solution can significantly decrease the $\mathrm{pH}$ [21]. This acidification of water is important in bacterial killer processes [22]. Based on the results obtained in this experiment the decrease in $\mathrm{pH}$ due to jet plasma exposure is 3.5. This condition indicates that the sample may turn into acid. Similar results were also found in previous studies [23]. 
A critical $\mathrm{pH}$ for bactericidal effects, which is approximately 4.7. Below the critical $\mathrm{pH}$, bacterial inactivation occurs by the plasma jet application to the solution surface meanwhile, above the critical $\mathrm{pH}$, bacteria remain intact even with the same plasma application [21]. Based on these results can be analogy that this process can kill bacteria that exist in the sample. Treatment of PAM by using plasma jet can be used for bacterial killings / sterilization.

Bacterial sterilization in PAM solution is one of the most widely developed medical plasma applications since bacteria are also present in aqueous conditions. This treatment can be applied to root canal sterilization in dentistry $[5,24]$ and prevent of surgical site infection [25]. Sterilization plasma using reduced-pH method in a PAM solution under acidic conditions $(\mathrm{pH}<4.8)$ occurs much more efficiently than neutral conditions $(\mathrm{pH} 6.5)$. In conditions $\mathrm{pH} 4.7$ some types of bacteria such as E. coli and L. citreum are inactivated. At $\mathrm{pH} 4.7$ condition is also called an estimate of "critical value", below which bacterial inactivation is extremely efficient and above which bacterial inactivation is relatively weak or hardly occurs [21].

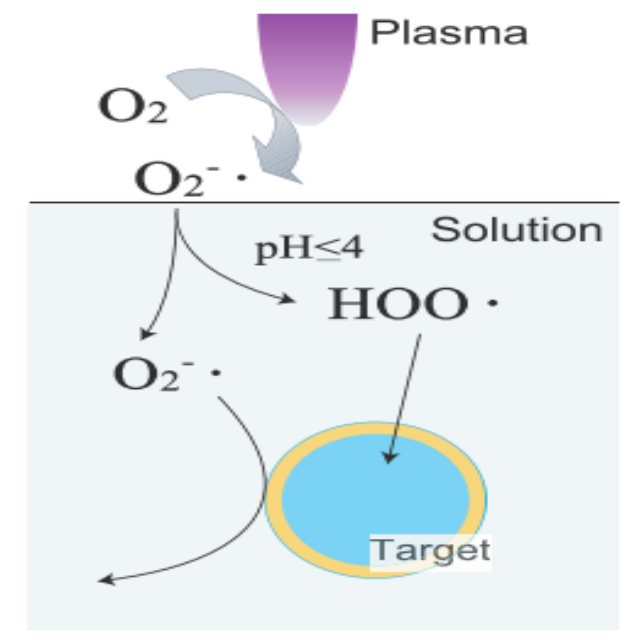

Fig. 5. Schematic mechanism of plasma sterilization in solution using plasma-induced chemical processing and the reduced $\mathrm{pH}$ method [26].

The schematic mechanism of plasma sterilization in solution using plasma-induced chemical processing and the reduced $\mathrm{pH}$ method is shown in figure 5 by Takai et al [26]. The plasma-generated $\mathrm{O}_{2} \bullet \bullet$ in air diffuses into the solution. $\mathrm{O}_{2} \cdot$ - in the solution is known to be in equilibrium with $\mathrm{HOO}$, as shown by the following reaction

$$
\mathrm{O}_{2} \bullet+\mathrm{H}^{+} \rightarrow \mathrm{HOO} \bullet \quad \mathrm{pKa}=4,8
$$

Here, pKa means the acid dissociation constant. This reaction shows that $\mathrm{O}_{2} \cdot \bullet$ is converted into $\mathrm{HOO} \bullet$ under lower $\mathrm{pH}$ conditions $(<4.8)$. Generally, the death rate of bacteria is known to be proportional to the concentration of the bactericidal factor. If the sterilization mechanism of the reduced $\mathrm{pH}$ method is actually involved in the neutralization of $\mathrm{O}_{2}{ }^{-} \cdot$ to $\mathrm{HOO} \cdot \mathrm{HOO} \cdot$ molecules can penetrate cell membranes and damage intercellular components [26]. This means that the reduced $\mathrm{pH}$ method is essential for the inactivation of bacteria in the body fluid, which contains $\mathrm{pH}$ buffering ability to control pH 7.4 [25].

It can be assumed that this study contributes to plasma treatment. Other researchers have also reported that plasma treatment effectively sterilizes bacteria in acidic conditions. Some researchers have tested bacterial inactivation rates with a reduced-pH method. Based on these tests, the rate of bacterial inactivation increases with decreasing $\mathrm{pH}$. The rate of bacterial inactivation increases with decreasing $\mathrm{pH}$. For example E. coli, C. rectus, S. aureus, Bacillus spore, Neurospora crassa are effectively inactivated on $\mathrm{pH} 3.7-4.5$ [26].

\subsection{Analysis of Ozone in PAM}

In this study Ozone analysis on plasma-activated medium is resulting from exposure to jet plasma to the sample. The sample of PAM used was aquadest with a volume of $25 \mathrm{ml}$. The sample is placed on a petri dish under the reactor. This treatment was performed with exposure time of 5 to 30 minutes with interval for 5 minutes with a distance (d) between electrode to plasmaactivated medium at 1,2 and $3 \mathrm{~cm}$. The Ozone measurements in the sample were performed using a Spectrophotometer Ozone (Ozone SAM I-2019 scale 0$5,0 \mathrm{ppm}$ ) with Ozone Kit (Ozone SAM I-2019). This treatment to determine concentrations of dissolved Ozone in PAM after treatment using plasma jet.

Based on the results obtained concentrations of Ozone on PAM can be seen in the graph shown in Figure 6 . Concentration ozone without jet plasma treatment $(0$ minutes) did not show the value (lo) on the Ozone Spectrophotometer, it can be write as $0 \mathrm{ppm}$. The samples without plasma treatment were used as control samples.

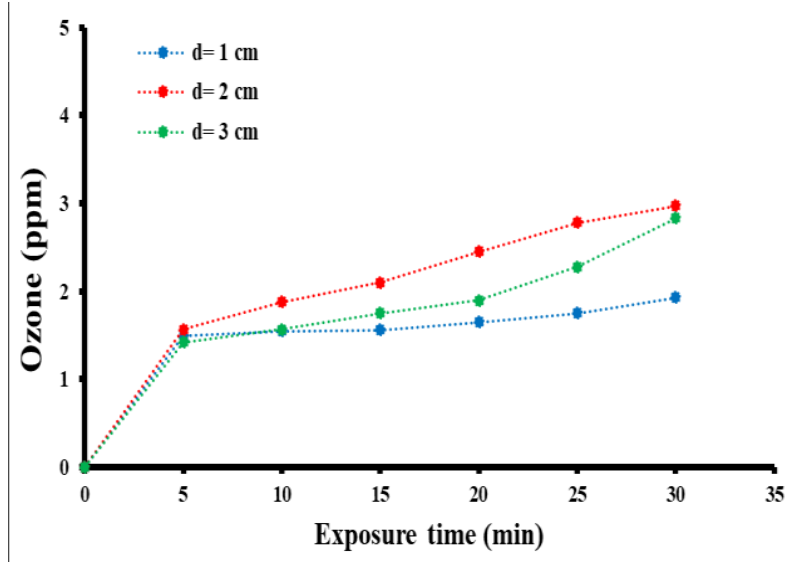

Fig. 6. Graph of ozone as functions of exposure time plasma jet.

The concentrations of dissolved ozone increase along with the rising of jet plasma exposure time. The concentration of ozone at $\mathrm{d}=2 \mathrm{~cm}$ is greater than $\mathrm{d}=1$ and $3 \mathrm{~cm}$. This is due to the production of $\mathrm{O}_{3}$ in the afterglow conditions produced by plasma jets. At distance (d) between electrode to plasma-activated medium $\mathrm{d}=1 \mathrm{~cm}$ 
plasma jet touched surface of the PAM so that $\mathrm{O}_{3}$ is generated slightly, at $\mathrm{d}=2$ there was a distance between the plasma jet and the surface of the PAM so that enough $\mathrm{O}_{3}$ is formed, at $\mathrm{d}=3$ the distance between the plasma jet and the surface of the PAM is too far so that the $\mathrm{O}_{3}$ is formed slightly. The highest concentration of ozone that can be produced is $2.97 \mathrm{ppm}$ with exposure time of 30 minutes at $\mathrm{d}=2 \mathrm{~cm}$.

This result is consistent with the measurement of concentrations $\mathrm{O}_{3}$ in PAM performed by Duan et al. The measurement of concentration $\mathrm{O}_{3}$ in the sample was using colorimetric and ozone kit method with different exposure time of plasma jet. Treatment without the exposure of plasma resulted in concentration $\mathrm{O}_{3}$ being below the detection limit at $0.05 \mathrm{mg} / \mathrm{l}$. On the other hand, when exposure plasma jet to PAM results in concentration $\mathrm{O}_{3} 1.29,2.58$ and $4.167 \mathrm{mg} / \mathrm{l}$ for the treatment time of 5, 10 and 15 minutes [27].

Ozone is another powerful oxidizing agent, which is known for bacterial killing and has been correlated with the biocidal properties of PAM generated by a plasma jet. $\mathrm{O}_{3}$ has an oxidizing potential of $2.07 \mathrm{eV}$. The dominant solute species produced by the gas phase process is $\mathrm{O}_{3} \cdot \mathrm{O}_{3}$ is produced in the gas phase and diffuses into the liquid into dissolved ozone. When dissolved, $\mathrm{O}_{3}$ can react with and oxidize organic compounds either directly or via radical intermediates. $\mathrm{O}$ is predominantly produced in the gas phase during jet plasma discharge by $\mathrm{O}_{2}$ dissociation process. Most $\mathrm{O}$ is used in $\mathrm{O}_{3}$ formation under afterglow conditions. This accumulation allows $\mathrm{O}_{3}$ to diffuse into water and dissolve. The $\mathrm{O}$ compound may also cause a reaction with dissolved $\mathrm{O}_{2}$ in the liquid phase to form dissolved $\mathrm{O}_{3}[18]$.

\subsection{Analysis of Hydrogen Peroxide}

In this study, analysis of Hydrogen Peroxide in plasma activated medium is resulting from exposure to jet plasma to the sample. The sample of PAM used was $\mathrm{H}_{2} \mathrm{O}_{2} \quad 30 \%$ dissolved by aquadest. $\mathrm{H}_{2} \mathrm{O}_{2} \quad 30 \%$ was dissolved by using aquadest to concentration of 1000 ppm with $25 \mathrm{ml}$ volume. The sample is placed on a petri dish under the reactor. This treatment was performed with exposure time of 5 to 30 minutes with interval for 5 minutes with a distance (d) between electrode to plasmaactivated medium at 1,2 and $3 \mathrm{~cm}$. The $\mathrm{H}_{2} \mathrm{O}_{2}$ measurements in the sample were performed using a Spectrophotometer Uv-Vis (Shimadzu UV Mini 1240). This treatment to determine concentrations of $\mathrm{H}_{2} \mathrm{O}_{2}$ in PAM after treatment using plasma jet.

$\mathrm{H}_{2} \mathrm{O}_{2}$ solution which will find its concentration value also inserted into spectrophotometer, so also obtained that is absorbance value and wavelength. The data used is the maximum absorbance value contained at the wavelength $286.5 \mathrm{~nm}$. Absorbance value can be convert into concentration with calculation and graph. The result can be used as the concentration value of $\mathrm{H}_{2} \mathrm{O}_{2}$ in PAM produced by Argon plasma jet. The concentration of $\mathrm{H}_{2} \mathrm{O}_{2}$ produced by exposure to jet plasma is shown in Figure 7.

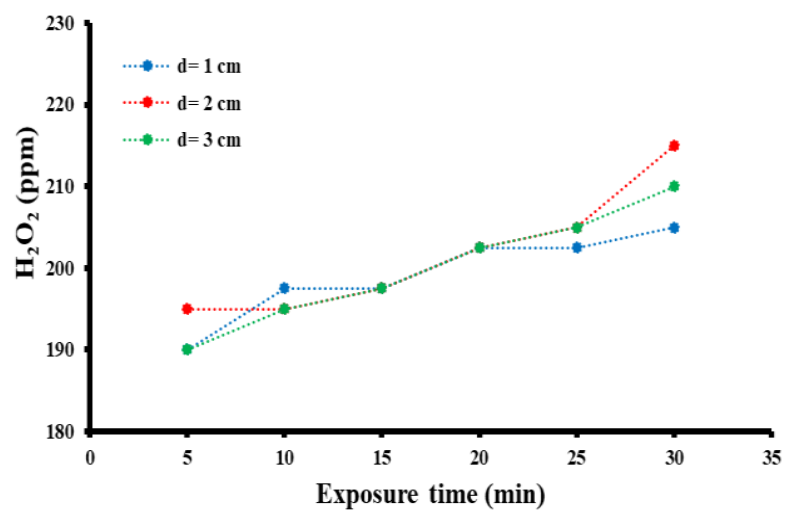

Fig. 7. Graph of $\mathrm{H}_{2} \mathrm{O}_{2}$ as functions of exposure time plasma jet.

This research resulted the highest concentration of $\mathrm{H}_{2} \mathrm{O}_{2}$ that is $215 \mathrm{ppm}(6056 \mu \mathrm{M})$ with exposure time for 30 minutes at $\mathrm{d}=2 \mathrm{~cm}$. The result of Hydrogen peroxide concentration increases with time of exposure. In this study, the concentration of $\mathrm{H}_{2} \mathrm{O}_{2} 179 \mu \mathrm{M}$ with exposure time for 1 minute. The concentration of $\mathrm{H}_{2} \mathrm{O}_{2}$ in the study is quite high when compared with some other research results. Some measurements of $\mathrm{H}_{2} \mathrm{O}_{2}$ concentrations with different plasma and media sources resulted in very different concentrations. The results of measurement of $\mathrm{H}_{2} \mathrm{O}_{2}$ concentrations from various references are shown in Table 1. The highest concentration of $\mathrm{H}_{2} \mathrm{O}_{2}$ that can be produced on DMEM media is $227 \mu \mathrm{M}$ with 1 minute exposure time, treatment using Ar $7 \mathrm{kV}$ jet plasma source with $2 \mathrm{~L} / \mathrm{min}$ gas flow discharge at reactor and PAM distance of $3 \mathrm{~mm}$. The lowest concentration of $\mathrm{H}_{2} \mathrm{O}_{2}$ was generated on aquadest medium of $3.6 \mu \mathrm{M}$ with exposure time of $1 \mathrm{~min}$, treatment using a $27 \mathrm{kV}$ DC plasma source at a distance between the reactor and a $12 \mathrm{~mm}$ PAM surface.

Table 1 Concentration of $\mathrm{H}_{2} \mathrm{O}_{2}$ generated by 1 minute plasma compared with other plasma sources results.

\begin{tabular}{|c|c|c|c|}
\hline Plasma sources & Medium & $\begin{array}{c}\text { Concentration } \\
\mathrm{H}_{2} \mathrm{O}_{2}(\mu \mathrm{M})\end{array}$ & Refs \\
\hline $\begin{array}{l}\text { Plasma jet Ar } 7 \mathrm{kV} \\
(2 \mathrm{~L} / \mathrm{m}) d=3 \mathrm{~mm}\end{array}$ & DMEM & 227 & [28] \\
\hline $\begin{array}{l}\text { Plasma jet Ar } 7 \mathrm{kV} \\
\quad(2 \mathrm{~L} / \mathrm{m}) d=13 \mathrm{~mm}\end{array}$ & DMEM & 18 & [29] \\
\hline $\begin{array}{l}\text { Plasma jet } 7 \mathrm{kV} \\
\quad(5 \mathrm{~L} / \mathrm{m}) d=22 \mathrm{~mm}\end{array}$ & MEM & 60 & [19] \\
\hline $\begin{array}{c}\text { Plasma jet Ar } 1 \mathrm{MHz} \\
6 \mathrm{kV} d=3 \mathrm{~L} / \mathrm{m}\end{array}$ & $\begin{array}{l}\text { RPMI + } \\
\text { FBS } 8 \%\end{array}$ & 33 & [30] \\
\hline $\begin{array}{l}\text { Plasma jet Ar } 1.1 \mathrm{MHz} \\
\quad d=3 \mathrm{~L} / \mathrm{m}\end{array}$ & $\begin{array}{l}\text { RPMI }+ \\
\text { FBS } 10 \%\end{array}$ & 60 & [31] \\
\hline RF Plasma Jet & aquadest & 14.5 & {$[32]$} \\
\hline DC $27 \mathrm{kV} d=12 \mathrm{~mm}$ & aquadest & 3.6 & [33] \\
\hline $\begin{array}{l}\text { DC Gas-Liquid } \\
6,5 \mathrm{kV} d=20 \mathrm{~mm}\end{array}$ & aquadest & 147 & [34] \\
\hline $\begin{array}{l}\text { Plasma Jet Ar } 12 \mathrm{kV} \\
(2 \mathrm{~L} / \mathrm{m}) d=20 \mathrm{~mm}\end{array}$ & $\begin{array}{l}\mathrm{H}_{2} \mathrm{O}_{2} 30 \% \\
+ \text { aquadest }\end{array}$ & 179 & \\
\hline
\end{tabular}

Increasing concentrations of $\mathrm{H}_{2} \mathrm{O}_{2}$ in $\mathrm{PAM}$ which is due to the increasing jet plasma exposure time was also produced by Mohades et al. In a study conducted by Mohades et al is using medium SCaBER MEM (Minimum Essential Media) and MDCK EMEM (Eagle's Minimum Essential Media). This medium is 
used to grow cancer cells. Increased concentration of $\mathrm{H}_{2} \mathrm{O}_{2}$ is shown in Figure 8. The $\mathrm{H}_{2} \mathrm{O}_{2}$ concentration was measured in MEM PAM immediately after plasma exposure and after 1,8 , and $12 \mathrm{~h}$ aging. To evaluate the effect of serum on $\mathrm{H}_{2} \mathrm{O}_{2}$ concentration, a serum-free PAM made by MEM and $1 \%$ antibiotics was used and the $\mathrm{H}_{2} \mathrm{O}_{2}$ concentration was measured after $8 \mathrm{~h}$ aging.

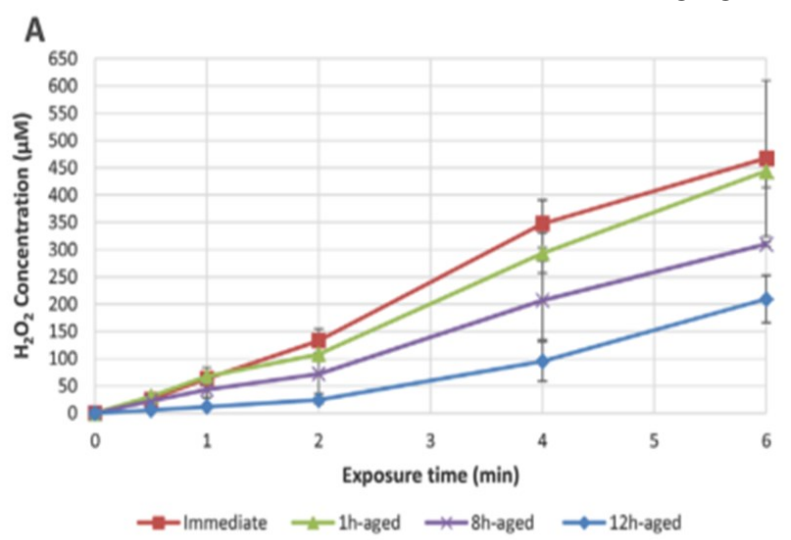

Fig. 8. Graph of $\mathrm{H} 2 \mathrm{O} 2$ as functions of exposure time plasma jet in MEM [19].

Measurement of $\mathrm{H}_{2} \mathrm{O}_{2}$ concentration was done by using Amplex red $\mathrm{H}_{2} \mathrm{O}_{2}$ assay kit. Measurements were performed immediately after treatment (immediate) and with a lag time of 1,8 , and 12 hours after plasma treatment. Direct measurement results obtained a maximum concentration of $\mathrm{H}_{2} \mathrm{O}_{2}$ of $460 \mu \mathrm{M}$ or 16.33 ppm $(1 \mathrm{M}=35500 \mathrm{ppm})$ with a 6 minute exposure time. In the measurement after 12 hours we get the value of $\mathrm{H}_{2} \mathrm{O}_{2}$ of $210 \mu \mathrm{M}$ or $7.45 \mathrm{ppm}$. The concentration of $\mathrm{H}_{2} \mathrm{O}_{2}$ in MEM medium increases with the duration of exposure time of jet plasma and the concentration of $\mathrm{H}_{2} \mathrm{O}_{2}$ on MEM medium decreases with time of storage. Based on these results showed that increasing $\mathrm{H}_{2} \mathrm{O}_{2}$ concentration along with increasing jet plasma exposure time. The concentration of $\mathrm{H}_{2} \mathrm{O}_{2}$ will decrease as time increases after exposure to jet plasma.

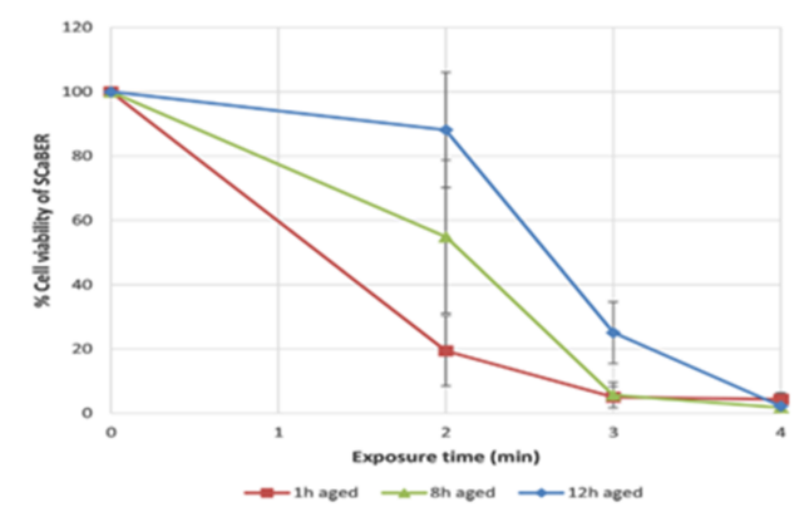

Fig. 9. Effectiveness of aged-PAM to induce cell death in SCaBER cells [19].

Figure 9 shows the age of PAM on the viability of SCaBER cells after treatment. PAMs were stored at room temperature for 1,8 , and 12 hours before testing using The Cell Titer $96 \AA$. In the study, the results of
SCaBER cell viability showed that PAM efficiency decreased with increasing age of PAM, depending on the duration of plasma exposure. The percentage of metabolically active cells declines with increasing exposure time. This shows that the efficiency of PAM to destroy cancer cells decreases with increasing aging time. PAM can induce more than $80 \%$ of cancer cell deaths [19].

\section{Conclusions}

In conclusion, it has been analysed that Atmospheric Pressure Plasma Jet can decreased $\mathrm{pH}$, increased temperature and increased concentrations of ozone and hydrogen peroxide in aqueous solutions. The maximum reactive species composition was obtained at the distance between reactor and plasma-activated medium of $2 \mathrm{~cm}$. The maximum composition of the reactive species produced in the plasma activated medium includes Ozone 2,97 ppm and Hydrogen peroxide 215 ppm. Ozone and Hydrogen peroxide are reactive species that fall into the category of Reactive Oxygen Species (ROS).

\section{References}

1. Nasruddin, Y. Nakajima, K. Mukai, H. S. E. Rahayu, M. Nur, T. Ishijima, H. Enomoto, Y. Uesugi, J. Sugama, and T. Nakatani, Clin. Plasma Med. 2, 28 (2014).

2. Nasruddin, Y. Nakajima, K. Mukai, E. Komatsu, H. S. E. Rahayu, M. Nur, T. Ishijima, H. Enomoto, Y. Uesugi, J. Sugama, and T. Nakatani, Plasma Process. Polym. 12, 1128 (2015).

3. T. von Woedtke, S. Reuter, K. Masur, and K. D. Weltmann, Phys. Rep. 530, 291 (2013).

4. K. Miyamoto, S. Ikehara, H. Takei, Y. Akimoto, H. Sakakita, K. Ishikawa, M. Ueda, J. Ikeda, M. Yamagishi, J. Kim, T. Yamaguchi, H. Nakanishi, T. Shimizu, N. Shimizu, M. Hori, and Y. Ikehara, Arch. Biochem. Biophys. 605, 1 (2016).

5. U. Emi, O. Tomoko, Y. Hiromitsu, I. Satoshi, K. Katsuhisa, M. Nobuko, and M. Yasuko, Jpn. J. Conserv. Dent. 58, 101 (2015).

6. M. Keidar, D. Yan, I. I. Beilis, B. Trink, and J. H. Sherman, Trends Biotechnol. xx, 1 (2017).

7. M. Wang, B. Holmes, X. Cheng, W. Zhu, M. Keidar, and L. G. Zhang, PLoS One 8, e73741 (2013).

8. J. W. Chang, S. U. Kang, Y. S. Shin, K. Il Kim, S. J. Seo, S. S. Yang, J. S. Lee, E. Moon, S. J. Baek, K. Lee, and C. H. Kim, Arch. Biochem. Biophys. 545, 133 (2014).

9. H. Tanaka, M. Mizuno, K. Ishikawa, K. Nakamura, F. Utsumi, H. Kajiyama, H. Kano, S. Maruyama, F. Kikkawa, and M. Hori, Plasma Med. 2, 207 (2012).

10. I. Yajima, M. Iida, M. Y. Kumasaka, Y. Omata, N. Ohgami, J. Chang, S. Ichihara, M. Hori, and M. Kato, Exp. Dermatol. 23, 424 (2014).

11. F. Utsumi, H. Kajiyama, K. Nakamura, H. Tanaka, M. Hori, and F. Kikkawa, Springerplus 3, 1 (2014). 
12. J. Huang, W. Chen, H. Li, X.-Q. Wang, G.-H. Lv, M. L. Khohsa, M. Guo, K.-C. Feng, P.-Y. Wang, and S.-Z. Yang, J. Appl. Phys. 109, 053305 (2011).

13. A. M. Hirst, M. S. Simms, V. M. Mann, N. J. Maitland, D. O'Connell, and F. M. Frame, Br. J. Cancer 112, 1536 (2015).

14. M. Ishaq, M. D. M. Evans, and K. K. Ostrikov, Biochim. Biophys. Acta - Mol. Cell Res. 1843, 2827 (2014).

15. J. Chauvin, F. Judée, M. Yousfi, P. Vicendo, and N. Merbahi, Sci. Rep. 7, 4562 (2017).

16. H. Tanaka, M. Mizuno, F. Kikkawa, and M. Hori, Plasma Med. 6, 101 (2016).

17. K.-D. Weltmann and T. von Woedtke, Plasma Phys. Control. Fusion 59, 014031 (2017).

18. W. Tian and M. J. Kushner, J. Phys. D. Appl. Phys. 47, 165201 (2014).

19. S. Mohades, N. Barekzi, H. Razavi, V. Maruthamuthu, and M. Laroussi, Plasma Process. Polym. 13, 1206 (2016).

20. M. Nur, A. W. Kinandana, P. Winarto, Z. Muhlisin, and Nasrudin, J. Phys. Conf. Ser. 776, 012102 (2016).

21. S. Ikawa, K. Kitano, and S. Hamaguchi, Plasma Process. Polym. 7, 33 (2010).

22. K. Oehmigen, M. Hähnel, R. Brandenburg, C. Wilke, K. D. Weltmann, and T. Von Woedtke, Plasma Process. Polym. 7, 250 (2010).

23. A. W. Kinandana, M. Nur, and Sumariyah, Int. J. Innov. Res. Adv. Eng. 5, 22 (2018).

24. V. Šantak, R. Zaplotnik, Z. Tarle, and S. Milošević, Appl. Spectrosc. 69, 1327 (2015).

25. K. Kitano, S. Ikawa, A. Tani, T. Ohshima, H. Yamaguchi, R. Arakawa, T. Kitamura, and N. Ohnishi, Proc. 20th Int. Plasma Chem. Soc. 270 (2011).

26. E. Takai, S. Ikawa, K. Kitano, J. Kuwabara, and K. Shiraki, J. Phys. D. Appl. Phys. 46, (2013).

27. J. Duan, X. Lu, and G. He, Phys. Plasmas 073506, (2017).

28. T. Adachi, H. Tanaka, S. Nonomura, H. Hara, S. I. Kondo, and M. Hori, Free Radic. Biol. Med. 79, 28 (2015).

29. N. Kurake, H. Tanaka, K. Ishikawa, T. Kondo, M. Sekine, K. Nakamura, H. Kajiyama, F. Kikkawa, M. Mizuno, and M. Hori, Arch. Biochem. Biophys. 605, 102 (2016).

30. J. Winter, H. Tresp, M. U. Hammer, S. Iseni, S. Kupsch, A. Schmidt-Bleker, K. Wende, M. Dünnbier, K. Masur, K.-D. Weltmann, and S. Reuter, J. Phys. D. Appl. Phys. 47, 285401 (2014).

31. S. Bekeschus, J. Kolata, C. Winterbourn, A. Kramer, R. Turner, K. D. Weltmann, B. Bröker, and K. Masur, Free Radic. Res. 48, 542 (2014).

32. P. Sun, Y. Sun, H. Wu, W. Zhu, J. L. Lopez, W. Liu, J. Zhang, R. Li, and J. Fang, Appl. Phys. Lett. 98, 021501 (2011).

33. P. Lukes, E. Dolezalova, I. Sisrova, and M. Clupek, Plasma Sources Sci. Technol. 23, (2014).

34. J. Shen, Q. Sun, Z. Zhang, C. Cheng, Y. Lan, H. Zhang, Z. Xu, Y. Zhao, W. Xia, and P. K. Chu, Plasma Process. Polym. 12, 252 (2015). 